\title{
Effect of Supplementing Different Levels of Organic Selenium \& Inorganic Selenium to Broiler Breeder Diet on Production Performance, Selenium Concentration in Plasma and Egg
}

\author{
Luma K. BanderS.J.Hamodi, Huda Q. Al-Hamdany \\ College of Agriculture/ University of Baghdad
}

\begin{abstract}
This study was carried out at the Poultry Research Station belong to state Board of Agricultural Research, Ministry of Agriculture, Abu Ghraib. The duration of this study was from 28 November 2013 to 15 May 2014 to evaluate the effect of supplementation different levels of organic selenium(Se-yeast) and inorganic selenium (Selenium selenite) on some productive performances of broiler breeder and selenium levels in plasma ,egg (yolk,albumin). The study included 336 female broiler breeder and 28 males (Ross 308 and arbor acres), 42 weeks old were randomly distributed to 7 dietary treatments experiment with 2 replicates / treatment (24 females and 2 male birds /replicate). The duration of the experiment was 24 weeks, and treatments were as the following: $C$ (Control diet) without supplement, $T_{1}, T_{2}$ and $T_{3}$ Supplementing with (Se-yeast) (0.2, 0.4 and 0.6 $\%$ ) respectively and $T_{4}, T_{5}$ and $T_{6}$ with (Selenium selenite) (0.2, 0.4 and $0.6 \%$ ) respectively. The results recorded a significant increase in hen day egg production $(H D \%)$ and egg weight ( $g)$ for the treatments $T_{2}(S e-$ yeast)and $T_{5}$ (Selenium selenite) respectively. however, the results showed no significant differences for egg mass ( $g$ ), feed conversion ratio (FCR) and eggs available for hatching (\%). Also, the results appeared that there were no significant differences $(P<0.05)$ between different sources and levels of selenium on its concentration in blood plasma. Nevertheless, the total concentrations of selenium for egg yolk and albumin were significantly higher for $T_{3}$ treatment which enrolled $12.16 \mu \mathrm{g} /$ egg compared with control group and $T_{4}$, which recorded 10.12 and $10.45 \mu \mathrm{g} / \mathrm{egg}$, respectively. Therefore, it was concluded that adding different levels and sources of Se had a significant effect on some productive performance, while organic selenium was more deposited in the internal egg components.
\end{abstract}

Keywords: Organic selenium, Inorganic selenium, Broiler breeder, Productive performance, selenium concentration

\section{Introduction}

Selenium (Se) has been recognized as an essential dietary nutrient that plays important roles in immune function health and productivity (Surai, 2002). Selenium is a structural component of the Glutathione Peroxidase enzyme system, which acts as an antioxidant that protects cellular components from oxidative stress (Larsen et al., 1997). Traditionally, the primary form of supplemental Se has been inorganic sodium selenite (NaSe). Recently, organic sources of Se such as Se-yeast, have been explored as an alternative to inorganic supplementation (Payne and Southern, 2005). The amount of Se available for assimilation by poultry tissues depends on the form and concentration of the element in the diet (Latshaw and Bigger, 1981; Choctel al., 2004). In our previous experiments, dietary Se increase Se concentration in meat of chickens (Downs et al,. 2000) and in eggs (Skrivanet al., 2008) more Se was deposited in egg white than in egg yolk. Organic Se has been shown to be effectively transferred from the diet of broiler breeders to the eggs and the tissues of day-old chicks (Surai, 2000; Paton et al., 2002).

Thus, the aim of the present study was to evaluate the effect of adding different forms of dietary Se (organic and inorganic) to investigate the effect of it on performance, hatchability and Se contents in plasma and eggs of broiler breeders.

\section{Birds and Dietary Treatments}

\section{Materials and Methods}

336 female broiler breeder and 28 males (Ross 308 and arbor acres), which aged 42 weeks old, were randomly distributed to 7 dietary treatments experimental period with 2 replicates /treatment ( 24 females and 2 males bird/replicate) The duration of the experiment was 24 weeks. Experimental treatments were as follow:C (Control diet) without supplement, $\mathrm{T}_{1}, \mathrm{~T}_{2}$ and $\mathrm{T}_{3}$ Supplementing with organic selenium $(0.2,0.4,0.6 \%$ ) respectively and $\mathrm{T}_{4}, \mathrm{~T}_{5}$ and $\mathrm{T}_{6}$ with inorganic selenium $(0.2,0.4,0.6 \%)$ respectively. All experimental diets were isonitrogenous and isocaloric and formulated to meet the National Research Council(NRC) (1994) requirements in the Table (1). 


\section{Parameter Studied}

The parameters studied in the present study include egg production rate, egg weight, egg mass, feed conversion ratio, eggs available for hatching (\%) and concentration of selenium in plasma, yolk and albumin egg.

\section{Statistical Analysis}

Data for bird performance were analyzed using the complete randomize design procedure of SAS software (2001). The statistical models included the main effect of diet, and means were considered to be statistically different at probability values of less than 0.05 .

Table 1.Composition of the experimental diets (\%)

\begin{tabular}{|l|l|}
\hline Ingredients & $\%$ \\
\hline Yellow Corn & 52.00 \\
\hline Wheat & 14.00 \\
\hline Soybean Meal (44\% CP) & 18.00 \\
\hline Meat Meal ${ }^{1}$ & 5.00 \\
\hline Hydrogenated Vegetable Fat & 2.65 \\
\hline Dicalcium Phosphate & 1.44 \\
\hline NaCl & 0.09 \\
\hline Limestone & 6.82 \\
\hline Total & $100 \%$ \\
\hline Calculated Values & \\
\hline M.E. Kcal/ Kg Diet & 2870 \\
\hline Crude Protein \% & 16.12 \\
\hline Lysine, \% & 0.86 \\
\hline Methionine \% & 0.376 \\
\hline Cystine \% & 0.265 \\
\hline Methionine Plus Cystine \% & 0.641 \\
\hline Arginine \% & 0.84 \\
\hline Ca \% $\%$ & 3.376 \\
\hline Available P, \% & 0.475 \\
\hline Linoleic \% & 1.25 \\
\hline & \\
\hline
\end{tabular}

${ }^{1}$ Protein Meal User Product From Netherlands Origin (Brocon) Contain 40\% Crude Protein, 2100 Kcal / Kg Protein M.E., 0.5\% Crude Fat ,2 \% Crude Fiber, 8\% Calcium, 2\% Phosphorus, 3.75\% Lysine ,2.85\%, Methionine $3.20 \%$, Methionine Plus Cystine. $2.20 \%$ sodium.

${ }^{2}$ Based on National Research Council recommendations (1994).

\section{Results and Discussion}

The results in table (2) showing the effect of adding organic and inorganic selenium on egg production traits of broiler breeder. The results indicated that the percentage of hen day production (HD \%) was significantly higher $(\mathrm{P}<0.05)$ for the treatment $\mathrm{T}_{2}$ compared with other treatments, especially $\mathrm{T}_{6}$. Also, the results in table (2) observed a significant increase $(\mathrm{P}<0.05)$ in egg weight for the treatments $\mathrm{T}_{5}$ and $\mathrm{T}_{6}$ which were 67.24 and $67.25 \mathrm{~g}$ respectively, compared with treatment T2 that is recorded the lowest egg weight which were $65.18 \mathrm{~g}$. however, the results showed no significant differences for egg mass (g), feed conversion ratio (FCR) and eggs available for hatching (\%).

Table 2: Effect of supplementing different levels of (se- yeast) and inorganic selenium (Selenium selenite) on

\begin{tabular}{|c|c|c|c|c|c|}
\hline Treatment & $\begin{array}{l}\text { H.D. \% } \\
\text { (Egg/Hen/day) }\end{array}$ & $\begin{array}{l}\text { Egg weight } \\
\text { (gm) }\end{array}$ & $\begin{array}{l}\text { Egg mass } \\
(\text { gm) }\end{array}$ & $\begin{array}{l}\text { (FCR) } \\
(\text { gm } \\
\text { egg/day) }\end{array}$ & $\begin{array}{l}\text { eggs available for } \\
\text { hatching } \\
\%\end{array}$ \\
\hline T1 & $67.96 \pm 4.09 a b$ & $66.02 \pm 3.11 a b$ & $44.86 \pm 2.79$ & $3.67 \pm 0.06$ & $66.91 \pm 3.51$ \\
\hline T2 & $69.36 \pm 4.47 a$ & $65.18 \pm 4.75 b$ & $45.20 \pm 3.02$ & $3.65 \pm 0.08$ & $68.53 \pm 3.77$ \\
\hline T3 & $66.18 \pm 3.17 a b$ & $66.51 \pm 2.86 a b$ & $44.01 \pm 2.35$ & $3.75 \pm 0.08$ & $65.10 \pm 3.09$ \\
\hline T5 & $63.94 \pm 3.71 \mathrm{ab}$ & $67.24 \pm 4.15 a$ & $42.99 \pm 2.52$ & $3.84 \pm 0.07$ & $63.12 \pm 3.06$ \\
\hline T6 & $62.66 \pm 2 . .89 b$ & $67.25 \pm 3.66 a$ & $42.13 \pm 1.85$ & $3.91 \pm 0.08$ & $61.87 \pm 2.71$ \\
\hline Significantly & $*$ & $*$ & N.S. & N.S. & N.S. \\
\hline
\end{tabular}

Means with different letters in the same column are significantly different $(\mathrm{p}<0.05)$

T1=OSY $0.2 \mathrm{mg} / \mathrm{kg}$ feed; T2= OSY $0.4 \mathrm{mg} / \mathrm{kg}$ feed; T3= OSY $0.6 \mathrm{mg} / \mathrm{kg}$ feed; $\mathbf{T} 4=$ Inorganic $\mathrm{Se} 0.2 \mathrm{mg} / \mathrm{kg}$ feed; T5= Inorganic Se $0.4 \mathrm{mg} / \mathrm{kg}$ feed; T6= Inorganic Se $0.6 \mathrm{mg} / \mathrm{kg}$ feed 
The increasing in hen day production (HD \%) that's appeared in this study (table 2) agreed with the results of Osman et al. (2010); Simon (2004) and Sara et al. (2008) that's noted an increasing in egg production when supplementing organic selenium to laying hens diets for different periods ranged from 42-65 weeks compared with control group.

The increase in egg production may be caused by the effect of selenium, the second element of iodine in the thyroid gland, which has a role in converting thyroxin T4 to triiodothiroxine T3, which is more effective in increasing metabolism by working selenium in increasing the efficiency of Iodothyronine deiodinase, which converts T4 to T3 (jianhua et al., 2000, fu). Selenium is an important factor in improving the productive performance of farm animals and domestic birds (Mahan, 1995)Yassin and Hassan, (2010) pointed to the role of selenium in pancreatic safety as it has a role in preventing pancreatic disease when used by $0.084 \mathrm{bpm}$ andthe role is essential for digestion of fat and absorption of vitamin E.Selenium is an essential component of the human body and animal for its important role in the action of the body's antioxidant system. Se is a key component of the antioxidant enzyme GSH-PH, which is present in most body tissues (Surai, 2002) of polyunsaturated fatty acids found in cell membranes. The increasing in this study (table 2) agreed with the results of Mohiti-Asliet al (2008) and Attia et al (2010) that have noted an increasing in egg weight when supplementing inorganic selenium to laying hens diets.

The results shown in table (3) clarify the effect of adding different levels and sources of selenium to broiler breeder diet on selenium levels in blood plasma and internal egg components. The results indicated that there were no significant differences $(\mathrm{P}<0.05)$ between different sources and levels of selenium on its concentration in blood plasma. Furthermore, there was a significant difference $(\mathrm{P}<0.05)$ in the level of selenium in egg yolk for the treatment $\mathrm{T}_{3}$ compared with control group which were 9.21 and $7.49 \mu \mathrm{g} / \mathrm{egg}$, respectively. While the concentration of selenium in egg albumin were increased significantly $(\mathrm{P}<0.05)$ for the treatments $\mathrm{T}_{3}$ and $\mathrm{T}_{6}$ which were 2.95 and $2.85 \mu \mathrm{g} /$ egg, respectively, compared with other experiment parameters, especially $\mathrm{T}_{1}$ that's recorded $2.34 \mu \mathrm{g} /$ egg. Nevertheless, the total concentrations of selenium for egg yolk and albumin were significantly higher for $\mathrm{T}_{3}$ treatment which enrolled $12.16 \mu \mathrm{g} / \mathrm{egg}$ compared with control group and $\mathrm{T}_{4}$, which recorded 10.12 and $10.45 \mu \mathrm{g} / \mathrm{egg}$, respectively.

Table 3: Effect of supplementing different levels of (se- yeast)and inorganic Selenium (Selenium selenite) on Se levels in plasma and egg of broiler breeder (Means \pm SE)

\begin{tabular}{|c|c|c|c|c|}
\hline Treatment & $\begin{array}{l}\text { Plasma } \\
(\mu \mathrm{g} / \mathrm{ml})\end{array}$ & $\begin{array}{l}\text { Yolk } \\
(\mu \mathrm{g} / \mathrm{egg})\end{array}$ & $\begin{array}{l}\text { Albumin } \\
(\mu \mathrm{g} / \mathrm{egg})\end{array}$ & $\begin{array}{l}\text { Yolk+Albumin } \\
\text { ( } \mu \text { g/whole egg) }\end{array}$ \\
\hline T1 & $0.168 \pm 0.02$ & $8.63 \pm 0.63 a b$ & $2.34 \pm 0.06 c$ & $10.97 \pm 0.61 \mathrm{cb}$ \\
\hline T3 & $0.190 \pm 0.04$ & $9.21 \pm 0.82 a$ & $2.95 \pm 0.11 a$ & $12.16 \pm 0.73 a$ \\
\hline T4 & $0.173 \pm 0.04$ & $7.63 \pm 0.60 \mathrm{cb}$ & $2.82 \pm 0.07 b$ & $10.45 \pm 0.66 c$ \\
\hline T5 & $0.176 \pm 0.03$ & $7.91 \pm 0.72 b$ & $2.76 \pm 0.08 a b$ & $10.67 \pm 70 \mathrm{cb}$ \\
\hline Significantly & N.S. & $* *$ & $* *$ & $* *$ \\
\hline
\end{tabular}

Means with different letters in the same column are significantly different $(\mathrm{p}<0.05)$.

T1=OSY $0.2 \mathrm{mg} / \mathrm{kg}$ feed; T2= OSY $0.4 \mathrm{mg} / \mathrm{kg}$ feed; T3= OSY $0.6 \mathrm{mg} / \mathrm{kg}$ feed; $\mathbf{T} 4=$ Inorganic Se $0.2 \mathrm{mg} / \mathrm{kg}$ feed; T5= Inorganic Se $0.4 \mathrm{mg} / \mathrm{kg}$ feed; T6= Inorganic Se $0.6 \mathrm{mg} / \mathrm{kg}$ feed.

Organic selenium is one of the elements that are absorbed into the animal's body with high efficiency compared to inorganic. In birds fed on inorganic (selenium selenite), an average of $4.25 \mathrm{mg} / \mathrm{kg}$ selenium is produced from the body compared to $1.32 \mathrm{mg} / \mathrm{kg}$ selenium fed on organic selenium (Se- yeast) (Payne and Southern, 2005). This is what we observed in this study, the high deposition of organic selenium by treatment T3 in egg components of yolk and albumin.In this experiment the organic type of selenium supplementation were found to be more effective and increasing selenium concentration in eggs than the inorganic Selenium. This illustrates the higher bioavailability of selenomethionine, the main selenium - compound of selenium- yeast ( schrauzer ,2000).the inorganic Selenium is passively absorbed, whereas selenomethionine is absorbed actively in the intestine by a process similar to that used for absorption of methionine (surai, 2002). Similar resultus regarding selenium concentration in eggs and meat have been reported when comparing inorganic dietary selenium to selenium yeast (Skrivan et al, 2006).It can be concluded from this study that selenium supplementation especially in organic from ( Se-yeats) of broiler breed diets are effective in increasing Se content of egg. Therefore the concentration of selenium will increase in growing fetal tissues and reducing the cases of fat oxidation which may happen in hatching eggs, moreover, adding organic selenium had improved the productive performance for broilers breeder. 


\section{References}

[1]. Attia.Y.A., A.A. Abdalah, H.S. Zeweil, F. Bovera, A.A. Tag El-Din,M.A. Araft .2010.Effect of inorganic or organic selenium supplementationon productive performance, egg quality and some physiological traits of dual-purpose breeding hens. J. Anim. Sci., 55, 2010 (11): 505-519

[2]. Choct M., Naylor A.J., Reinke N.2004. Selenium supplementation affects broiler growth performance,meat yield and feather coverage. Brit. Poult. Sci., 45, 677-683.

[3]. Downs, K.M., Hess, J.B. and Bilgili, S.F. (2000) Selenium Source Effect on Broiler Carcass Characteristics, Meat Quality and Drip Loss. Journal of Applied Animal Research, 18, 61-72.

[4]. Larsen, C.T. , F.W. Pierson and W.B. Gross .1997. Effect of dietary selenium on the response of stressed and unstressed chickens to Escherichia coli challenge and antigen. Biological Trace Element Research 58: 169-176.

[5]. Latshaw , J. D. , and M. D. Biggert. 1981. Incorporation of selenium into egg proteins after feeding selenomethionine or sodium selenite. Poult.Sci. 60:1309-1313.

[6]. Mohiti-Asli, M., Shariatmadari, F., Lotfollahian, H. and Mazuji, M. T. 2008. Effects of supplementing layer hen diets with selenium and vitamin E on egg quality, lipid oxidation and fatty acid composition during storage. Can. J. Anim. Sci. 88:475 _483.

[7]. NRC .1994.National Research Council. Nutrient requirementsof poultry.9th ed. National Academy Press. Washington, USA.

[8]. Osman, A.M.R., Abdel Wahed, H.M. and Ragab, M.S. 2010.Effects of supplementing laying hens diets with organic selenium on egg production, egg quality, fertility and hatchability.Egypt. Poult. Sci. 30 (3): 893-915.

[9]. Pappas A., Acamovic T., Sparks N., Surai P., McDevitt R.2005. Effects of supplementing broiler breeder diets with organic selenium and polyunsaturated fatty acids on egg quality during storage, Poult. Sci., vol. 84 (pg. 865-874)

[10]. Paton N.D., Cantor A.H., Pescatore A.J., Ford M.J., SmithC.A. (2002): The effect of dietary selenium source andlevel on the uptake of selenium by developing chickembryos. Poultry Science, 81, 1548-1554.

[11]. Payne R.L, Lavergne T.K., Southern L.L. (2005). Effect of inorganic versus organic selenium on hen production and egg selenium concentration.Poultry Science, 84,232-237.

[12]. SAS. 2001. SAS User's Guide, Version 8.2. SAS Institute, Cary, NC

[13]. Sara, A.; Bennea, M.; Odagiu, A. and Panta, L. 2008. Effects of the organic selenium (Sel-Plex) administered in laying hens' feed in second laying phase on production performances and the eggs quality. Bulletin UASVM Animal Science and Biotechnologies, 65:1-

[14]. Schrauzer, G.N..2000.Selenomethionine: a review of its nutritional significance,metabolism and toxicity. Journal of Nutrition.130:1653-1656.

[15]. Simon, S. 2004.Alltech symposium highlights . World Poult. 20 :12-13.

[16]. Skrivan, M., M. Marounek, G. Dlouha, and S. Seucitova. 2008.Dietary selenium increases vitamin E contents of egg yolk andchicken meat. Br. Poult. Sci. 49:482-486.

[17]. Surai, P. F. 2000. Effect of selenium and vitamin E content of the maternal diet on the antioxidant system of the yolk and the developing chick. Br. Poult. Sci. 41:235-243.

[18]. Surai, P.F. 2002.Selenium in poultry nutrition 1.Antioxidant properties, deficiency and toxicity, World's Poult. Sci. J. vol. 58 (pg. 333-347). 